\title{
Inheritance of Resistance to Aflatoxin Production and Aspergillus Ear Rot of Corn from the Cross of Inbreds B73 and Oh516
}

\author{
K. N. Busboom and D. G. White
}

University of Illinois, Department of Crop Sciences, Urbana 61801.

Accepted for publication 8 June 2004.

\begin{abstract}
Busboom, K. N., and White, D. G. 2004. Inheritance of resistance to aflatoxin production and Aspergillus ear rot of corn from the cross of inbreds B73 and Oh516. Phytopathology 94:1107-1115.

Our objective was to determine the value of corn (Zea mays) inbred Oh516 as a source of resistance to Aspergillus ear rot and aflatoxin accumulation in grain. Types and magnitudes of gene action associated with resistance were determined with generation means analysis. Molecular markers associated with resistance were identified from $\mathrm{BCP}_{1} \mathrm{~S}_{1}$ families developed from the cross of the susceptible inbred B73 and

in grain, percent bright greenish yellow fluorescence (BGYF), and severity of Aspergillus ear rot following inoculation in Urbana, IL. BCP $\mathrm{S}_{1}$ families testcrossed with LH185 also were evaluated at three locations in 2002. Molecular marker-quantitative trait loci (QTL) associations with all traits were determined with single factor analysis of variance. Dominance gene action was associated with aflatoxin concentration in grain and percent BGYF. QTL associated with aflatoxin accumulation in grain were identified on chromosomes 2, 3, and 7 (bins 2.01 to 2.03, 2.08, 3.08, and 7.06). Alleles from inbred Oh516 on chromosomes 2, 3, and 7 should improve resistance of commercially used, B73-type inbreds.
\end{abstract} Oh516. In 2001 and 2002, B73 $\left(\mathrm{P}_{1}\right), \mathrm{Oh} 516\left(\mathrm{P}_{2}\right)$, and the $\mathrm{F}_{1}, \mathrm{~F}_{2}, \mathrm{~F}_{3}, \mathrm{BCP}_{1}$, $\mathrm{BCP}_{2}$, and $\mathrm{BCP}_{1} \mathrm{~S}_{1}$ generations were evaluated for aflatoxin concentration
Additional keywords: Aspergillus flavus, maize, mycotoxins.
Aspergillus ear rot of corn (Zea mays L.), caused by Aspergillus flavus Link:Fr., is an economic concern of producers and consumers because it is associated with aflatoxin $\mathrm{B}_{1}$, the most carcinogenic of the aflatoxins. Humans and animals that consume aflatoxin $\mathrm{B}_{1}$ may be affected detrimentally $(2,13,18,19)$. The U.S. Food and Drug Administration (FDA) prohibits interstate commerce of grain that has aflatoxin concentration equal to or greater than $20 \mathrm{ng} / \mathrm{g}(4,30)$. Aflatoxin $\mathrm{M}_{1}$, the hydroxylated homologue of aflatoxin $\mathrm{B}_{1}$, may be found in milk or milk products from livestock that have consumed aflatoxin-contaminated feed (19). Interstate commerce of milk products containing $0.5 \mathrm{ng} / \mathrm{g}$ of aflatoxin $\mathrm{M}_{1}$ or greater is prohibited by the FDA $(4,30)$. Severe infection of corn by A. flavus in the field is typical in the southern United States, but infection is severe in the Midwestern Corn Belt generally only during years when rainfall is below average and temperature is above average $\left(36\right.$ to $\left.38^{\circ} \mathrm{C}\right)(10,30)$.

Presence of $A$. flavus in corn can be determined qualitatively by observing bright greenish yellow fluorescence (BGYF). BGYF is produced when a heat labile enzyme in the kernel oxidizes kojic acid, a compound produced by A. flavus $(1,24,33)$. BGYF can be detected in the germ or endosperm of the kernel with a $365 \mathrm{~nm}$ ultraviolet light. Grain elevator personnel commonly look for BGYF as an initial, presumptive test to identify corn samples that may require chemical analysis for aflatoxin.

Studies have reported a high correlation between BGYF and aflatoxin concentration in corn $(22,26,31,33)$. One study evaluating the relationship between BGYF and aflatoxin concentration in hybrids grown in South Carolina and Florida reported a significant correlation of $r=0.85$ (22). In 2000 and 2001, a study of segregating generations developed from the cross of B73 $\times$ MI82 reported significant $(P=0.001)$, positive correlations $(r=$ 0.75 and 0.79 ) for aflatoxin concentration in grain and percent

Corresponding author: D. G. White; E-mail address: donwhite@uiuc.edu

Publication no. P-2004-0816-04R

(c) 2004 The American Phytopathological Society
BGYF (26). False positives, corn samples that indicate BGYF but contain no aflatoxin, are a disadvantage of using BGYF as an indirect test for aflatoxin concentration in grain $(21,23,37,39)$. False negatives in grain samples also have been reported where samples contain aflatoxin but no visible BGYF has been detected (37).

Several methods for reducing severity of Aspergillus ear rot and aflatoxin concentration in corn grain have been suggested, but the most effective and economical method is the development of resistant hybrids $(28,30)$. Resistance to Aspergillus ear rot and resistance to aflatoxin accumulation in grain are quantitatively inherited $(14,17,27,35)$. Gene action associated with resistance to Aspergillus ear rot and aflatoxin accumulation in grain has been determined with studies of diallel mating designs $(9,14,15,38)$. These studies provide different results depending on the environment and the inbreds evaluated. However, two studies reported that general combining ability had a greater effect on resistance to aflatoxin accumulation in grain than specific combining ability and that inheritance for lower aflatoxin concentration in grain is additive $(9,38)$.

Inbred Oh516 was developed at the Ohio State University Agricultural Research and Developmental Center from the cross $($ B14 $\times$ L97) $\times$ B14. The hybrid testcross Oh516 $\times$ B73 had low aflatoxin concentration in grain and low severity of Aspergillus ear rot when over 2,000 testcrosses were evaluated in inoculated trials in 1991 (7). Of 32 resistant inbreds selected as testcrosses for low aflatoxin concentration in grain, Oh516 $\times$ B73 was not significantly different from the most resistant testcross Tex6 $\times$ B73. In a later study, six of the more promising inbreds (CI2, 75R001, LB31, Oh513, Oh516, and Tex6) and two susceptible inbreds (B73 and Mo17) were evaluated for low aflatoxin concentration in grain and resistance to Aspergillus ear rot in a diallel mating design (29). $F_{1}$ crosses developed with inbreds Oh516 or Tex6 had lower aflatoxin concentration in grain than crosses without Oh516 or Tex6. The $\mathrm{F}_{1}$ cross Oh516 $\times$ Tex6 had the lowest aflatoxin concentration in grain of all $\mathrm{F}_{1}$ crosses. General combining abilities for low aflatoxin concentration in grain and 
low ear rot severity were highly significant for crosses developed with Oh516 or Tex6.

Inbred B73 was developed through improvements of Stiff Stalk Synthetic, a population derived primarily from inbred lines related to open pollinated cv. Reid Yellow Dent (34). Reid Yellow Dent was widely grown in the United States prior to the 1940s. Inbred lines related to Stiff Stalk Synthetic and Reid Yellow Dent are widely used commercially as maternal parents of hybrids grown in the United States. All lines related to Stiff Stalk Synthetic and Reid Yellow Dent were susceptible to Aspergillus ear rot and aflatoxin accumulation in grain in our evaluations in 1994 (7). Therefore, alleles for resistance from Oh516 that contribute resistance to B73 could prove to be of value for improving a significant proportion of commercial corn hybrids in the United States.

Our objectives were to determine the types and magnitudes of gene action associated with resistance to aflatoxin accumulation in grain, percent BGYF, and Aspergillus ear rot in crosses developed with Oh516 and B73; to determine heritabilities and predicted gain from selection for resistance to aflatoxin accumulation in grain, percent BGYF, and severity of Aspergillus ear rot in segregating populations developed with inbreds Oh516, B73, and commercial inbred LH185; to re-evaluate the usefulness of indirect selection for low aflatoxin concentration in grain based on percent BGYF in a segregating population; and to identify quantitative trait loci (QTL) associated with resistance to aflatoxin accumulation in grain, percent BGYF, and severity of Aspergillus ear rot in segregating populations developed with inbreds Oh516, B73, and LH185.

\section{MATERIALS AND METHODS}

Generation means study. Seed of the susceptible parent B73 $\left(\mathrm{P}_{1}\right)$, the resistant parent $\mathrm{Oh} 516\left(\mathrm{P}_{2}\right)$, and the $\mathrm{F}_{1}, \mathrm{~F}_{2}, \mathrm{~F}_{3}, \mathrm{BCP}_{1}$, $\mathrm{BCP}_{2}$, and $\mathrm{BCP}_{1} \mathrm{~S}_{1}$ generations developed with $\mathrm{B} 73$ and Oh516 were planted at Urbana, Illinois on 27 April 2001 and 22 May 2002. Generations were developed by crossing B73 $\times$ Oh516 $\left(F_{1}\right)$, self-pollinating the $\mathrm{F}_{1}\left(\mathrm{~F}_{2}\right)$, self-pollinating the $\mathrm{F}_{2}\left(\mathrm{~F}_{3}\right)$, backcrossing the $\mathrm{F}_{1}$ to $\mathrm{B} 73\left(\mathrm{BCP}_{1}\right)$ or Oh516 $\left(\mathrm{BCP}_{2}\right)$, and self pollinating the $\mathrm{BCP}_{1}\left(\mathrm{BCP}_{1} \mathrm{~S}_{1}\right)$. The experiment was a randomized complete block design with two replicates. Replicates consisted of 15 rows each of the $\mathrm{P}_{1}, \mathrm{P}_{2}, \mathrm{~F}_{1}, \mathrm{~F}_{2}, \mathrm{BCP}_{1}$, and $\mathrm{BCP}_{2}$ generations, 30 rows of the $F_{3}$ generation, and 265 rows (families) of the $\mathrm{BCP}_{1} \mathrm{~S}_{1}$ generation. Experimental units were single rows that were $5.3 \mathrm{~m}$ long, spaced $0.8 \mathrm{~m}$ apart, and included approximately 24 plants. All rows or families were grouped together by generation to minimize interplot competition. Generations were randomized within replicates.

Inoculum was prepared, and ears were inoculated with the same isolates and technique that have been used successfully to differentiate resistant and susceptible germ plasm in studies at the University of Illinois since $1991(5,17,26,35)$. Four isolates of equal mixture of conidia from $A$. flavus were used as inoculum. One isolate was obtained from corn grain collected in Illinois in 1988 and the other three isolates $(6536,6539$, and 6540) came from the Northern Regional Research Laboratory, Peoria, IL. Isolates were grown in petri dishes on potato dextrose agar (Becton Dickinson and Company, Sparks, MD) for about 2 weeks. Deionized water was added to the cultures and blended. The spore suspension was filtered through a double layer of cheesecloth. The resulting spore suspension was adjusted to either $1 \times$ $10^{6}$ spores per $\mathrm{ml}$ or $2 \times 10^{6}$ spores per $\mathrm{ml}$ by dilution with distilled water. Two drops of Tween 20 per $100 \mathrm{ml}$ were added. Approximately 7 days after midsilk, $10 \mathrm{ml}$ of the $1 \times 10^{6}$ spores per ml suspension was injected down the silk channel of the primary ear of each plant. One week later, $10 \mathrm{ml}$ of the $2 \times 10^{6}$ spores per ml suspension was injected through the husks of the primary ears using a pinboard inoculator (7).
Inoculated ears were harvested when kernels reached $18 \%$ or less grain moisture and dried with forced air at approximately $32^{\circ} \mathrm{C}$ to $14 \%$ grain moisture. Ears were visually rated for severity of Aspergillus ear rot as percentage of the inoculation site with symptoms. Ears were rated using a scale of 0 to $100 \%$ in equal increments of $5 \%$, with $0 \%$ being no visible ear rot to $100 \%$ being completely rotted at the inoculation site.

Grain was shelled from cobs, bulked by experimental unit, and ground with a Romer Grinding/Subsampling Mill (Model 2A; Romer Labs Inc., Union, MO) to pass through a 1-mm screen. A 2 -g sample of ground grain from each experimental unit was analyzed three times and averaged for aflatoxin $\mathrm{B}_{1}$ using an indirectcompetitive enzyme linked immunosorbent assay (ELISA) modified from Campbell and White (6). A 25-g sample of ground grain from each experimental unit was visually rated for BGYF. Samples were measured into a plastic petri plate and rated under a $365 \mathrm{~nm}$ ultraviolet light. Samples were rated twice, averaged, and expressed as percent BGYF. Individual samples were mixed between ratings. Samples were rated on a scale of 0 to $100 \%$ in equal increments of $5 \%$, with $0 \%$ being no BGYF and $100 \%$ being complete BGYF.

Generation means for aflatoxin concentration in grain, percent BGYF, and severity of Aspergillus ear rot were calculated by averaging experimental units within a generation. Aflatoxin concentration in grain was transformed with the natural log function, and percent BGYF and severity of Aspergillus ear rot were transformed with the square root function to homogenize variances between generations. Transformations were completed with Statistical Analysis System (SAS) software (SAS Institute, Cary, NC) using the univariate (PROC UNIVARIATE) procedure. Effects of years, replicates, generations, and the interactions of these factors on aflatoxin concentration in grain, percent BGYF, and severity of Aspergillus ear rot were analyzed with the general linear model (PROC GLM) procedure in SAS. Years and replicates nested within years were considered random effects and generations were considered fixed.

Generation means analysis followed Mather and Jinks' notation and method (25). Means of the generations were fitted to the additive-dominance genetic model: $Y=m+c y+a_{1} x_{(2001)}+$ $a_{2} x_{(2002)}+b_{1} d+b_{2} h$, in which $Y=$ generation mean, $m=$ intercept value, $y=$ year effect, $x_{(2001)}=$ replicate effect in 2001, $x_{(2002)}=$ replicate effect in 2002, $d=$ pooled additive gene effects, and $h=$ pooled dominance effects. The data were fitted to the model using the regression (PROC REG) procedure in SAS. The additivedominance model was tested by an $F$ test to determine if deviations from the model were significant. If the deviations were not significant, the model was considered adequate. If deviations were significant, a model was tested that included epistasis in the form of digenic interactions. If deviations were significant, the data were fitted to the equation $Y=m+c y+a_{1} x_{(2001)}+a_{2} x_{(2002)}+$ $b_{1} d+b_{2} h+b_{3} h$, in which $Y=$ generation mean, $m=$ intercept value, $y=$ year effect, $x_{(2001)}=$ replicate effect in 2001, $x_{(2002)}=$ replicate effect in 2002, $d=$ pooled additive gene effects, $h=$ pooled dominance effects, and $i=$ additive-additive interaction. Potence ratios were calculated by dividing the dominant parameter estimate by the additive parameter estimate for natural logtransformed aflatoxin concentration in grain and square roottransformed percent BGYF (16).

Heritabilities for resistance to natural log-transformed aflatoxin concentration in grain, square root-transformed percent BGYF, and square root-transformed severity of Aspergillus ear rot were estimated from the $\mathrm{BCP}_{1} \mathrm{~S}_{1}$ families with the equation $h^{2}=$ $\sigma_{\text {BCP1S1 }}^{2} /\left[\left(\sigma_{e}^{2} / r y\right)+\left(\sigma_{g e}^{2} / y\right)+\sigma_{\text {BCP1S1 }}^{2}\right]$, where $\sigma_{\text {BCP1S1 }}^{2}$ is the variance among the $\mathrm{BCP}_{1} \mathrm{~S}_{1}$ families, $\sigma_{e}^{2}$ is the pooled error variance, $r$ is the number of replicates, $y$ is the number of years, and $\sigma_{g e}^{2}$ is the family by year variance (16). Variance components for the effects of years, replicates within years, families, and families by years were estimated with the variance components 
(PROC VARCOMP) procedure in SAS. All effects were considered random. Predicted gain from selection was calculated using the following formula (16): $\Delta_{G}=\left[k(1 / 2) \sigma_{A}^{2}\right] / \sigma_{p}$, where $k$ is a constant based on selection intensity, $\sigma_{A}^{2}$ is the additive genetic variance, and $\sigma_{p}$ is the square root of the phenotypic variance among $\mathrm{BCP}_{1} \mathrm{~S}_{1}$ family means. Genetic gain was calculated with a $20 \%$ selection intensity $(k=1.3998)(25)$.

Pearson's correlation coefficients for aflatoxin concentration in grain, percent $\mathrm{BGYF}$, and severity of Aspergillus ear rot were calculated on $\mathrm{BCP}_{1} \mathrm{~S}_{1}$ family means with the correlation (PROC CORR PEARSON) procedure in SAS. Correlation coefficients were calculated with nontransformed data.

Testcross trial. Two hundred seventeen of the $\mathrm{BCP}_{1} \mathrm{~S}_{1}$ families evaluated in the generation means study were crossed with LH185 (Holden's Foundation Seeds, Williamsburg, IA; BCP $\mathrm{S}_{1}$ families $\times$ LH185) in 2001. Seed of the 217 testcrosses were planted at Urbana, IL; Ganado, TX; and Batesville, TX in 2002. Plots in Texas were provided by Monsanto Company (St. Louis, MO). The experiment was a randomized complete block design with two replicates. Experimental units were single rows that were approximately $5.3 \mathrm{~m}$ long, spaced $0.8 \mathrm{~m}$ apart, and included approximately 24 plants. Families were randomized within each replication. Plots near Batesville, TX, were furrow irrigated with approximately $51 \mathrm{~cm}$ of water throughout the growing season.

Inoculum and inoculations for the testcross trial at Urbana were as described for the generation means study. Inoculum for the testcross trials in Texas was prepared with a technique similar to that described by Maupin et al. (27). Inoculum was prepared by first autoclaving corn in micropore bags (Model D2X-bag; Northwest Mycological Consultants, Corvallis, OR), inoculating with conidia of A. flavus, and incubating at room temperature for 3 weeks. Eight kilograms of inoculated corn with sporulating A. flavus was mixed with $600 \mathrm{ml}$ of cottonseed oil to suspend conidia in the oil. Four kilograms of oil-corn mixture was added to $20 \mathrm{~kg}$ of autoclaved corn in a cement mixer. The mixer was run for $5 \mathrm{~min}$ and $350 \mathrm{~g}$ of diatomaceous earth was added to the mixer to adhere the oil and conidia onto the corn kernels. The resulting inoculum, corn coated with A. flavus conidia, was stored in a cooler at $5.6^{\circ} \mathrm{C}$ until use (approximately 2 weeks) and shipped to Texas. Five grams of inoculum was placed in the leaf whorl of each plant at the V9 to V10 growth stage.

Primary ears were harvested at approximately $18 \%$ or less grain moisture. Ears from the trial at Urbana were visually rated for severity of Aspergillus ear rot as described in the generation means study. Ears from the trials in Texas were not visually rated for severity of Aspergillus ear rot. Grain was shelled, bulked, ground, analyzed for aflatoxin concentration, and analyzed for percent BGYF as described in the generation means study.

$\mathrm{BCP}_{1} \mathrm{~S}_{1}$ testcross means for aflatoxin concentration in grain and percent $\mathrm{BGYF}$ were calculated for each of the three locations. Analysis of variance for natural log-transformed aflatoxin concentration in grain and square root-transformed percent BGYF were calculated with data from all locations with PROC GLM in SAS. Locations and replicates within locations were considered random effects and families were considered fixed effects. $\mathrm{BCP}_{1} \mathrm{~S}_{1}$ testcross means for severity of Aspergillus ear rot were calculated with data from Urbana only. Analysis of variance for square root-transformed severity of Aspergillus ear rot was calculated with data from Urbana only with PROC GLM in SAS. Replicates were considered random effects and families were considered fixed effects.

Heritabilities for natural log-transformed aflatoxin concentration in grain and square root-transformed percent BGYF were estimated for $\mathrm{BCP}_{1} \mathrm{~S}_{1}$ testcrosses with data from all three locations. Heritability for square root-transformed severity of Aspergillus ear rot was estimated for the $\mathrm{BCP}_{1} \mathrm{~S}_{1}$ testcrosses with data from Urbana only. Heritability was estimated with the equation $h^{2}=\sigma_{\mathrm{BCP} 1 \mathrm{~S} 1}^{2} /\left[\left(\sigma_{e}^{2} / r y\right)+\sigma_{\mathrm{BCP} 1 \mathrm{~S} 1}^{2}\right]$, where $\sigma_{\mathrm{BCP} 1 \mathrm{~S} 1}^{2}$ is the variance among the $\mathrm{BCP}_{1} \mathrm{~S}_{1}$ testcrosses, $\sigma_{e}^{2}$ is the pooled error variance, $r$ is the number of replicates, and $y$ is the number of locations (16). Variance components were estimated with PROC VARCOMP in SAS. All effects were considered random. Predicted gains from selection for resistance to natural log-transformed aflatoxin concentration in grain, square root-transformed percent BGYF, and square root-transformed severity of Aspergillus ear rot were estimated for the $\mathrm{BCP}_{1} \mathrm{~S}_{1}$ testcrosses as described in the generation means study.

Pearson's correlation coefficients for aflatoxin concentration in grain and percent $\mathrm{BGYF}$ were calculated on $\mathrm{BCP}_{1} \mathrm{~S}_{1}$ testcross means with the PROC CORR PEARSON procedure of SAS. Correlations were calculated with nontransformed data.

QTL study. Two hundred seventeen families of the $\mathrm{BCP}_{1} \mathrm{~S}_{1}$ generation evaluated in the generation means study were genotyped by Monsanto Company. A genetic linkage map consisting of 96 single nucleotide polymorphism (SNP) markers was developed with phenotypic data from the $217 \mathrm{BCP}_{1} \mathrm{~S}_{1}$ families and their $\mathrm{BCP}_{1} \mathrm{~S}_{1}$ testcrosses evaluated in 2002. Markers and methods are proprietary to Monsanto Company; therefore, they cannot be reported here. Instead, bin numbers and public simple sequence repeat markers (SSR) (20) that correspond approximately to the location of the SNP markers are reported. Single factor analysis of variance was completed with PROC GLM in SAS.

\section{RESULTS}

Above average temperature and below average rainfall made conditions favorable for Aspergillus ear rot and aflatoxin accumulation in corn grain at Urbana, IL, in June, July, and August 2001 and 2002. Weather conditions in Texas also were extremely hot and dry in 2002, making conditions favorable for Aspergillus ear rot and aflatoxin accumulation in grain. Batesville, located in southwestern Texas, received $19.3 \mathrm{~cm}$ of rainfall in April, May, and June, which is $26.9 \mathrm{~cm}$ below normal for that area of Texas. Due to consistently low levels of rainfall in that area of Texas, irrigation was necessary to ensure plant growth and survival. Ganado, located in southeastern Texas, received more rainfall throughout the growing season than Batesville. Ganado received $15.2 \mathrm{~cm}$ of total rainfall in April and May, and received $12.7 \mathrm{~cm}$ of rainfall in June, which is slightly above normal for that area of Texas.

Generation means study. Aflatoxin concentration in grain differed significantly $(P=0.002)$ among generations produced with B73 and Oh516 (Table 1). Aflatoxin concentration in grain

TABLE 1. Analysis of variance for aflatoxin concentration in corn grain, percent bright greenish yellow fluorescence (BGYF), and severity of Aspergillus ear rot for B73, Oh516, and six generations produced with B73 and Oh516 in 2001 and $2002^{a}$

\begin{tabular}{lrccc}
\hline Source of variation & df & $\begin{array}{c}\text { Aflatoxin }^{\mathrm{b}} \\
\text { (mean square) }\end{array}$ & $\begin{array}{c}\mathrm{BGYF}^{\mathrm{c}} \\
\text { (mean square) }\end{array}$ & $\begin{array}{c}\text { Ear rot }^{\mathrm{d}} \\
\text { (mean square) }\end{array}$ \\
\hline Year & 1 & 0.15 & 2.35 & 1.87 \\
Replicates (year) & 2 & $0.22^{* *}$ & 0.33 & $0.98^{* *}$ \\
Generation & 7 & $0.40^{* *}$ & $5.40^{* *}$ & 1.73 \\
Generation $\times$ year & 7 & 0.03 & $0.60^{*}$ & $0.68^{* *}$ \\
Pooled error & 14 & 0.03 & 0.17 & 0.14 \\
Coefficient of variation & & 3.36 & 10.78 & 8.56 \\
\hline
\end{tabular}

a $*, * *$, and $* * *$ indicate significance at $\alpha=0.05,0.01$, and 0.001 , respectively.

b Measured by indirect-competitive enzyme-linked immunosorbent assay. Samples were analyzed in triplicate, and values were averaged. Data were natural log-transformed prior to statistical analysis.

c Ground samples were rated on a percent scale, with $100 \%$ being the most susceptible. Samples were visually rated twice, and values were averaged. Samples were stirred between ratings. Data were square root-transformed prior to statistical analysis.

d Primary ears from all plants were visually rated for percentage of inoculated area affected by Aspergillus ear rot. Ratings were expressed on a 0 to $100 \%$ scale $(0=0 \%, 100=100 \%$ rotted $)$. Data were square root-transformed prior to statistical analysis. 
was not affected significantly by the year or generation-year interaction. Treatment means for aflatoxin concentration in grain ranged from 129 to $541 \mathrm{ng} / \mathrm{g}$ in 2001 and from 183 to $477 \mathrm{ng} / \mathrm{g}$ in 2002 (Table 2). In 2001 and 2002, the $F_{1}$ generation had the lowest aflatoxin concentration in grain, whereas the susceptible parent B73 had the greatest aflatoxin concentration in grain. Aflatoxin concentration in grain from the $F_{1}$ generation was significantly lower than the calculated midparent value in 2001 and $2002(P<0.05)$, indicating dominance for resistance.

TABLE 2. Aflatoxin concentrations in corn grain, percent bright greenish yellow fluorescence (BGYF), and severity of Aspergillus ear rot for B73, Oh516, and six generations produced with B73 and Oh516 in 2001 and 2002

\begin{tabular}{lcccccccc}
\hline & \multicolumn{2}{c}{ Aflatoxin $(\mathrm{ng} / \mathrm{g})^{\mathrm{b}}$} & & \multicolumn{2}{c}{$\mathrm{BGYF}(\%)^{\mathrm{c}}$} & & \multicolumn{2}{c}{ Ear rot $(\%)^{\mathrm{d}}$} \\
\cline { 2 - 3 } \cline { 7 - 8 } Generation $^{\mathrm{a}}$ & 2001 & 2002 & & 2001 & 2002 & & 2001 & 2002 \\
\hline $\mathrm{P}_{1}$ (B73) & 541 & 477 & & 53 & 36 & & 45 & 24 \\
$\mathrm{P}_{2}$ (Oh516) & 193 & 274 & & 7 & 13 & & 13 & 15 \\
$\mathrm{~F}_{1}$ & 129 & 183 & & 6 & 14 & & 24 & 12 \\
$\mathrm{~F}_{2}$ & 172 & 241 & & 8 & 15 & & 20 & 23 \\
$\mathrm{~F}_{3}$ & 228 & 268 & & 12 & 16 & & 16 & 18 \\
$\mathrm{BCP}_{1}$ & 167 & 247 & & 10 & 18 & & 23 & 20 \\
$\mathrm{BCP}_{2}$ & 214 & 194 & & 10 & 14 & & 19 & 10 \\
$\mathrm{BCP}_{1} \mathrm{~S}_{1}$ & 277 & 329 & & 19 & 22 & & 23 & 21 \\
\hline
\end{tabular}

a The $F_{1}$ is the cross $B 73 \times$ Oh516. $F_{2}$ and $F_{3}$ generations were produced by self-pollinating $\mathrm{F}_{1}$ and $\mathrm{F}_{2}$ plants, respectively. The $\mathrm{BCP}_{1}$ and $\mathrm{BCP}_{2}$ generations were produced by crossing $\mathrm{F}_{1}$ plants with $\mathrm{B} 73$ and $\mathrm{Oh} 516$, respectively. The $\mathrm{BCP}_{1} \mathrm{~S}_{1}$ generation was produced by selfing the $\mathrm{BCP}_{1}$ plants.

${ }^{b}$ Measured by indirect-competitive enzyme-linked immunosorbent assay. Aflatoxin values are the mean of three replications and are nontransformed. ${ }^{c}$ Ground samples were rated for BGYF on a percent scale of 0 to $100 \%$ in equal increments of 5\%, with $100 \%$ being the most susceptible. Values presented are the average of two ratings and are nontransformed.

${ }^{d}$ Primary ears from all plants were visually rated for the percentage of inoculated area affected by Aspergillus ear rot. Ratings were expressed on a 0 to $100 \%$ scale in equal increments of $5 \%$, with $100 \%$ being fully rotted at the inoculation site. Values are based on the nontransformed data.

TABLE 3. Least squares estimates of the parameters of the model ${ }^{\mathrm{a}}$ used in generation means analysis of aflatoxin ${ }^{\mathrm{b}}$ concentration in corn grain and percent bright greenish yellow fluorescence (BGYF) ${ }^{\mathrm{c}}$ in 2001 and $2002^{\mathrm{d}}$

\begin{tabular}{lccc}
\hline Parameter & $\begin{array}{c}\text { Parameter } \\
\text { estimate }\end{array}$ & Standard error & $\begin{array}{c}\text { T for H0: } \\
\text { parameter }=0\end{array}$ \\
\hline Aflatoxin & & & \\
$m$ & 5.46 & 0.06 & $93.00^{* * * *}$ \\
$y$ & -0.07 & 0.04 & -1.82 \\
$x_{(2001)}$ & 0.11 & 0.05 & 2.20 \\
$x_{(2002)}$ & -0.12 & 0.05 & $-2.31^{*}$ \\
$d$ & 0.29 & 0.06 & $4.53^{* * *}$ \\
$h$ & -0.66 & 0.12 & $-5.49^{* * *}$ \\
Potence ratio & -0.23 & $\ldots$ & $\ldots$ \\
BGYF-2001 & & & \\
$m$ & 4.36 & 0.35 & $12.59^{* * *}$ \\
$x$ & 0.17 & 0.22 & 0.79 \\
$d$ & 1.71 & 0.37 & $4.58^{* * *}$ \\
$h$ & -2.42 & 0.71 & $-3.39^{* * *}$ \\
Potence ratio & -1.42 & $\ldots$ & $\ldots$ \\
BGYF-2002 & & & \\
$m$ & 4.43 & 0.14 & $32.34^{* * * *}$ \\
$x$ & -0.11 & 0.09 & -1.2 \\
$d$ & 1.06 & 0.15 & $7.20^{* * *}$ \\
$h$ & -1.04 & 0.28 & $-3.71^{* *}$ \\
Potence ratio & -0.98 & $\ldots$ & $\ldots$ \\
\hline
\end{tabular}

a The model fitted was $Y=m+c y+a_{1} x_{(2001)}+a_{2} x_{(2002)}+b_{1} d+b_{2} h$ for aflatoxin concentration in grain and percent BGYF. The parameters of the equation are $Y=$ generation mean, $m=$ intercept value, $x=$ block effect, $d=$ pooled additive effects, and $h=$ pooled dominance effects.

b Values were natural log-transformed prior to statistical analysis.

${ }^{c}$ Values were square root-transformed prior to statistical analysis.

$\mathrm{d} *, * *$, and $* * *$ indicate significance at $\alpha=0.05,0.01$, and 0.001 , respectively.

e The potence ratio was calculated by dividing the dominance parameter estimate by the additive parameter estimate.
Deviations from the additive-dominance model were not significant for aflatoxin concentration in grain; therefore, epistasis was not an important factor for resistance to aflatoxin accumulation in grain. Pooled additive and dominant gene effects for aflatoxin concentration in grain were highly significant $(P=0.0001)$ (Table 3). Dominant, additive, and residual gene effects accounted for $47.4,35.8$, and $16.8 \%$ of the variation among generations. The potence ratio for aflatoxin concentration in grain was -0.23 , indicating partial dominance for resistance. Aflatoxin concentration in grain among $\mathrm{BCP}_{1} \mathrm{~S}_{1}$ families did not differ significantly $(P<$ 0.05 ); therefore, family variance components were zero (Table 4 ), and heritability and gain from selection for low aflatoxin concentration in grain could not be determined.

Percent BGYF differed significantly $(P=0.004)$ among generations produced with B73 and Oh516 (Table 1). Percent BGYF was not affected significantly by year, but was affected significantly $(P=0.022)$ by the generation-year interaction. Treatment means for percent BGYF ranged from 6 to $53 \%$ in 2001 and from 13 to $36 \%$ in 2002 (Table 2). The susceptible parent B73 had the greatest percent BGYF in 2001 and 2002. The $F_{1}$ generation had the least percent BGYF in 2001, while the resistant parent Oh516 had the least percent BGYF in 2002.

Since percent BGYF was affected significantly by the generation-year interaction, gene action associated with low levels of percent BGYF was determined for individual years. Deviations from the additive-dominance model were not significant for percent BGYF; therefore, epistasis was not an important factor affecting low percent BGYF in 2001 and 2002. Pooled additive and dominant gene effects associated with percent BGYF were highly significant $(P<0.05)$ (Table 3$)$ in 2001 and 2002. Additive, dominant, and residual gene effects accounted for 51.7, 26.6, and $21.7 \%$ of the variation in percent BGYF among generations in 2001, respectively. Additive, dominant, and residual gene effects accounted for 70.8, 18.0, and $11.3 \%$ of the variation in percent BGYF among generations in 2002, respectively. Parameter

TABLE 4. Estimates of variance component, heritability, and expected gain from selection for aflatoxin concentration in corn grain, percent bright greenish yellow fluorescence (BGYF), and severity of Aspergillus ear rot from $265 \mathrm{BCP}_{1} \mathrm{~S}_{1}{ }^{a}$ families evaluated in 2001 and 2002

\begin{tabular}{lccc}
\hline Variance component & Aflatoxin $^{\mathrm{b}}$ & BGYF $^{\mathrm{c}}$ & Ear rot $^{\mathrm{d}}$ \\
\hline Year & 0.00 & 0.07 & 0.00 \\
Replicates (year) & 0.01 & 0.01 & 0.07 \\
Family & 0.00 & 0.11 & 0.03 \\
Family $\times$ year & 0.04 & 0.10 & 0.00 \\
Pooled error & 0.51 & 1.47 & 0.97 \\
Heritability $\left(h^{2}\right)^{\mathrm{e}}$ & $\mathrm{NE}^{\mathrm{f}}$ & 21.12 & 11.28 \\
Expected gain from selection $\left(\Delta_{G}\right)^{\mathrm{g}}$ & $\mathrm{NE}$ & 0.01 & 0.00 \\
\hline
\end{tabular}

a Backcrossed to the susceptible parent (B73) and selfed once.

b Measured by indirect-competitive enzyme-linked immunosorbent assay. Samples were analyzed in triplicate, and values were averaged. Values were natural $\log$-transformed prior to statistical analysis.

${ }^{c}$ Ground samples were rated on a percent scale, with $100 \%$ being most susceptible. Ground grain samples were visually rated twice, and values were averaged. Samples were stirred between ratings. Values were square root-transformed prior to statistical analysis.

d Primary ears from all plants were visually rated as the percentage of inoculated area affected by Aspergillus ear rot. Ratings were expressed on a 0 to $100 \%$ scale $(0=0 \%, 100=100 \%$ rotted $)$. Values were square root-transformed prior to statistical analysis.

e Heritabilities were calculated using the equation $h^{2}=\sigma_{\mathrm{BCP} 1 \mathrm{~S} 1}^{2} /\left[\left(\sigma^{2} e_{e} / r y\right)+\right.$ $\left.\left(\sigma_{g e}^{2} / y\right)+\sigma^{2}{ }_{\mathrm{BCP} 2 \mathrm{~S} 1}\right]$, where $\sigma_{\mathrm{BCP} 1 \mathrm{~S} 1}^{2}$ is the variance among $\mathrm{BCP}_{1} \mathrm{~S}_{1}$ families, $\sigma_{e}^{2}$ is the pooled error variance, $r$ is the number of replicates, $y$ is the number of years, and $\sigma_{g e}^{2}$ is the generation by year variance. Heritabilities were expressed as a percent.

$\mathrm{f}$ Values were not estimable due to a lack of significance among families.

$\mathrm{g}$ Gain from selection was calculated with the equation $\Delta_{G}=\left[k(1 / 2) \sigma^{2}{ }_{A}\right] / \sigma_{p}$, where $k$ is the constant 1.3998 (20\% selection intensity), $\sigma_{A}^{2}$ is genetic variance among $\mathrm{BCP}_{1} \mathrm{~S}_{1}$ families, and $\sigma_{p}$ is the square root of the phenotypic variance among $\mathrm{BCP}_{1} \mathrm{~S}_{1}$ families. 
estimates for dominant gene effects were negative in 2001 and 2002, indicating dominance for low percent BGYF. Potence ratios for percent BGYF were -1.42 and -0.98 , indicating overdominance for low levels of percent BGYF in 2001 and dominance for low levels of percent BGYF in 2002. Heritability for low percent BGYF among $\mathrm{BCP}_{1} \mathrm{~S}_{1}$ families was $21.1 \%$ (Table 4 ).

Severity of Aspergillus ear rot was affected significantly $(P=$ 0.005 ) by the generation-year interaction (Table 1$)$. Severity of Aspergillus ear rot was not affected significantly $(P>0.05)$ by the main effects of generations or years. Treatment means for severity of Aspergillus ear rot ranged from 13 to $45 \%$ in 2001 and from 10 to $24 \%$ in 2002 (Table 2). The susceptible parent B73 had the greatest severity of Aspergillus ear rot in 2001 and 2002. The resistant parent Oh516 had the least severity of Aspergillus ear rot in 2001, while the $\mathrm{BCP}_{2}$ generation had the least severity of Aspergillus ear rot in 2002.

Since severity of Aspergillus ear rot was not affected significantly by the main effects of generations, gene action associated with resistance was not determined. Heritability for resistance to severity of Aspergillus ear rot among $\mathrm{BCP}_{1} \mathrm{~S}_{1}$ families was $11.3 \%$ (Table 4).

Correlation coefficients for aflatoxin concentration in grain and percent $\mathrm{BGYF}$ among $\mathrm{BCP}_{1} \mathrm{~S}_{1}$ families were highly significant $(P=0.001)$ in $2001(r=0.67)$ and $2002(r=0.57)$ (Table 5). Correlation coefficients also were significant $(P=$ $0.001)$ for aflatoxin concentration in grain and severity of Aspergillus ear rot $(r=0.53)$ and for percent BGYF and severity of Aspergillus ear rot $(r=0.49)$ in 2001. However, correlation coefficients $(P>0.05)$ for these two relationships were not significant in 2002.

Testcross trial. Aflatoxin concentration in grain was affected significantly by locations $(P=0.0002)$ and families $(P=0.012)$, but was not affected significantly by the family-location interaction $(P>0.05)$ (Table 6). Treatment means for aflatoxin concentration in grain of the $\mathrm{BCP}_{1} \mathrm{~S}_{1}$ families $\times \mathrm{LH} 185$ were $162 \mathrm{ng} / \mathrm{g}$ at Urbana, IL; $525 \mathrm{ng} / \mathrm{g}$ at Ganado, TX; and 2,469 ng/g at Batesville, TX (Table 7). Heritability for low aflatoxin concentration in grain was greatest $(29.1 \%)$ when estimated with data from Ganado, TX (Table 8). Heritability for low aflatoxin concentration in grain was low when estimated with data from Urbana, IL, and Batesville, TX (1.0 and 2.7\%, respectively).

Percent BGYF was affected significantly by locations $(P=$ 0.002 ), but not by families or family-location interaction (Table 6 ). The grand mean of percent $\mathrm{BGYF}$ from the $\mathrm{BCP}_{1} \mathrm{~S}_{1}$ families $\times$ LH185 was $10 \%$ at Ganado, TX; $17 \%$ at Urbana, IL; and $34 \%$ at Batesville, TX (Table 7). Heritability for low percent BGYF could not be determined at Urbana, Batesville, or Ganado because there were no significant differences $(P>0.05)$ between testcross families (Table 6).
Testcrosses of $\mathrm{BCP}_{1} \mathrm{~S}_{1}$ families $\times$ LH185 were not visually rated for severity of Aspergillus ear rot in the two trials in Texas. Severity of Aspergillus ear rot was not affected significantly by the main effects of families at Urbana, IL (Table 6). The grand mean of severity of Aspergillus ear rot from the $\mathrm{BCP}_{1} \mathrm{~S}_{1}$ families $\times$ LH185 at Urbana was $15 \%$ (Table 7). Heritability for resistance to severity of Aspergillus ear rot at Urbana was not estimable because ear rot did not differ significantly among $\mathrm{BCP}_{1} \mathrm{~S}_{1}$ families $\times$ LH185 (Table 8 ).

QTL study. Molecular markers associated with low percent BGYF and low severity of Aspergillus ear rot were identified among $\mathrm{BCP}_{1} \mathrm{~S}_{1}$ families (Table 9). Molecular markers associated with low aflatoxin concentration in grain and low severity of Aspergillus ear rot were identified among $\mathrm{BCP}_{1} \mathrm{~S}_{1}$ families $\times$ LH185 (Table 9). Molecular markers associated with low aflatoxin concentration in grain among $\mathrm{BCP}_{1} \mathrm{~S}_{1}$ families and markers associated with low percent $\mathrm{BGYF}$ among $\mathrm{BCP}_{1} \mathrm{~S}_{1}$ families $\times$

TABLE 6. Analysis of variance for aflatoxin concentrations in corn grain, percent bright greenish yellow fluorescence (BGYF), and severity of Aspergillus ear rot for $217 \mathrm{BCP}_{1} \mathrm{~S}_{1}$ families crossed with LH185 in $2002^{\mathrm{a}}$

\begin{tabular}{|c|c|c|}
\hline Source of variation & df & Mean square \\
\hline \multicolumn{3}{|l|}{ Aflatoxin $^{\mathrm{b}}$} \\
\hline Location & 2 & $782.11 * * *$ \\
\hline Replicates (location) & 3 & $1.82 * *$ \\
\hline Family & 216 & $0.52 * *$ \\
\hline Family $\times$ location & 430 & 0.44 \\
\hline Pooled error $($ C.V. $=10.31)$ & 642 & 0.41 \\
\hline \multicolumn{3}{|l|}{$\mathrm{BGYF}^{\mathrm{c}}$} \\
\hline Location & 2 & $807.90 * * *$ \\
\hline Replicates (location) & 3 & $7.22 * * *$ \\
\hline Family & 216 & 0.94 \\
\hline Family $\times$ location & 430 & 0.89 \\
\hline Pooled error $($ C.V. $=23.58)$ & 642 & 0.98 \\
\hline \multicolumn{3}{|l|}{ Ear $\operatorname{rot}^{\mathrm{d}}$} \\
\hline Replicates & 1 & $7.26 * *$ \\
\hline Family & 214 & 1.03 \\
\hline Pooled error (C.V. $=26.53)$ & 214 & 0.98 \\
\hline \multicolumn{3}{|c|}{$\begin{array}{l}\text { b Measured by indirect-competitive enzyme-linked immunosorbent assay. } \\
\text { Samples were analyzed in triplicate, and values were averaged. Data were } \\
\text { natural log-transformed prior to statistical analysis. }\end{array}$} \\
\hline \multicolumn{3}{|c|}{$\begin{array}{l}\text { c Ground samples were rated on a percent scale, with } 100 \% \text { being the most } \\
\text { susceptible. Samples were visually rated twice, and values were averaged. } \\
\text { Samples were stirred between ratings. Data were square root-transformed } \\
\text { prior to statistical analysis. }\end{array}$} \\
\hline \multicolumn{3}{|c|}{$\begin{array}{l}\text { d Primary ears from all plants were visually rated for percentage of inoculated } \\
\text { area affected by Aspergillus ear rot. Ratings were expressed on a } 0 \text { to } 100 \% \\
\text { scale }(0=0 \%, 100=100 \% \text { rotted). Data were square root-transformed prior } \\
\text { to statistical analysis. Data is only from Urbana, } 2002 \text {. }\end{array}$} \\
\hline
\end{tabular}

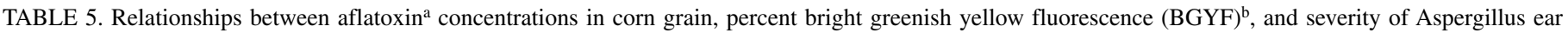

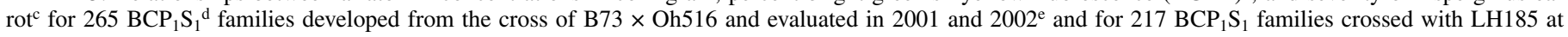
three locations in 2002

\begin{tabular}{|c|c|c|c|c|c|}
\hline \multirow[b]{3}{*}{ Pairs of dependent variables } & \multicolumn{5}{|c|}{ Pearson's correlation coefficient } \\
\hline & \multicolumn{2}{|c|}{$\mathrm{BCP}_{1} \mathrm{~S}_{1}$} & \multirow{2}{*}{$\begin{array}{c}\text { Urbana, IL } \\
2002 \\
\end{array}$} & \multirow{2}{*}{$\begin{array}{c}\text { Ganado, TX } \\
2002\end{array}$} & \multirow{2}{*}{$\begin{array}{c}\text { Batesville, TX } \\
2002\end{array}$} \\
\hline & 2001 & 2002 & & & \\
\hline Aflatoxin $(\mathrm{ng} / \mathrm{g}) \times$ BGYF $(\%)$ & $0.67 * *$ & $0.57 * *$ & $0.42 * *$ & $0.42 * *$ & 0.21 \\
\hline Aflatoxin $(\mathrm{ng} / \mathrm{g}) \times$ ear rot $(\%)$ & $0.53 * *$ & 0.01 & $\ldots$ & $\ldots$ & $\ldots$ \\
\hline $\operatorname{BGYF}(\%) \times$ ear rot $(\%)$ & $0.49 * *$ & 0.04 & $\ldots$ & $\ldots$ & $\ldots$ \\
\hline
\end{tabular}

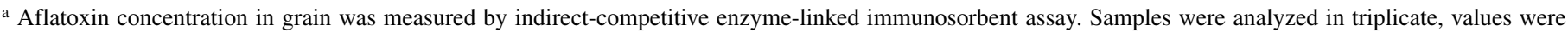
averaged, and are nontransformed.

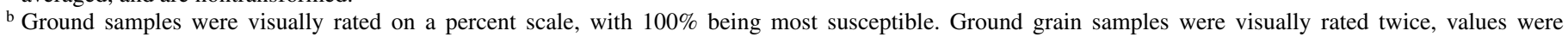
averaged, and are nontransformed. Samples were stirred between ratings.

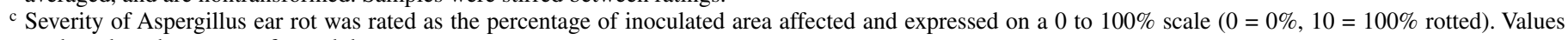
are based on the nontransformed data.

${ }^{\mathrm{d}}$ Backcrossed to the susceptible parent (B73) and selfed once.

e Asterisks (**) indicate difference is statistically significant at $P=0.001$. 
LH185 could not be reliably identified because differences between families and testcrosses were not apparent. Where molecular markers could be associated with resistance, most of the favorable chromosome regions came from the resistant inbred Oh516 and few of the favorable regions came from the susceptible inbred B73. Significant associations between markers and low aflatoxin concentration in grain from the $\mathrm{BCP}_{1} \mathrm{~S}_{1}$ families $\times \mathrm{LH} 185$ were identified on chromosome bins 2.01 to $2.03,2.06,3.08$, and 7.06. All of the marker-resistance associations for aflatoxin were attributed to chromosome regions from the resistant inbred Oh516.

Significant associations between markers and low percent BGYF were identified from the $\mathrm{BCP}_{1} \mathrm{~S}_{1}$ family population on chromosome bins 1.03 to $1.09,2.04,2.05,5.01$ to 5.06 , and 9.01 to 9.07. Marker-resistance associations attributed to regions from the susceptible inbred B73 were identified in bins 8.03 and 9.07. All other marker-resistance associations were attributed to regions from Oh516.

Markers associated with low severity of Aspergillus ear rot were identified among $\mathrm{BCP}_{1} \mathrm{~S}_{1}$ families evaluated in the generation means study and among $\mathrm{BCP}_{1} \mathrm{~S}_{1}$ families testcrossed to LH185. Significant marker-resistance associations among $\mathrm{BCP}_{1} \mathrm{~S}_{1}$ families were attributed to chromosome regions from Oh516 in bins 1.02 to $1.07,2.03$ to $2.06,4.06$ to 4.09 , and 5.03 to 5.07 . Significant marker-resistance associations among $\mathrm{BCP}_{1} \mathrm{~S}_{1}$ families were attributed to regions from B73 in bins 7.03, 7.04, and 7.05. Significant marker-resistance associations among testcross families were attributed to regions from Oh516 in bins 1.03, 1.12, 2.04 to $2.06,4.06,5.05$, and 6.02 to 6.06 . One marker-resistance association among testcross families was attributed to a region from $\mathrm{B} 73$ in bin 3.03.

\section{DISCUSSION}

Marker assisted selection enhances the precision and speed of the selection process for traits such as resistance to aflatoxin concentration in grain that are quantitatively inherited and poorly heritable $(11,12)$. Heritability estimates for low aflatoxin concentration in grain, low percent BGYF, and low severity of Aspergillus ear rot from $\mathrm{BCP}_{1} \mathrm{~S}_{1}$ families derived from the cross of $\mathrm{B} 73 \times$ Oh516 and/or those families crossed with LH185 were small; therefore, selection of families with low levels of these traits will be difficult. Marker assisted selection in a backcross breeding program speeds identification of favorable alleles for resistance, aides in incorporating favorable alleles into an agronomically superior, commercially acceptable inbred, and reduces seasonal

TABLE 7. Aflatoxin concentrations in corn grain, percent bright greenish yellow fluorescence (BGYF), and severity of Aspergillus ear rot for the $\mathrm{BCP}_{1} \mathrm{~S}_{1}$ families test crossed with LH185 and evaluated at three locations in 2002

\begin{tabular}{|c|c|c|c|}
\hline Location $^{a}$ & Aflatoxin $(n g / g)^{b}$ & $\operatorname{BGYF}(\%)^{\mathrm{c}}$ & Ear rot $(\%)^{\mathrm{d}}$ \\
\hline Urbana, IL & 162 & 17 & 15 \\
\hline Ganado, TX & 525 & 10 & $\mathrm{NR}^{\mathrm{e}}$ \\
\hline Batesville, TX & 2,469 & 34 & NR \\
\hline
\end{tabular}

${ }^{a}$ Each location consisted of $217 \mathrm{BCP}_{1} \mathrm{~S}_{1}$ families test crossed with LH185. The values are the averages of each replication. Batesville was furrow irrigated with $50.8 \mathrm{~cm}$ of water throughout the growing season.

b Measured by indirect-competitive enzyme-linked immunosorbent assay. Samples were analyzed in triplicate, values were averaged, and values are based on the nontransformed data.

c Ground samples were rated for fluorescence on a percent scale of 0 to $100 \%$ in equal increments of $5 \%$, with $100 \%$ being the most susceptible. Samples were rated two times, values were averaged, and values are based on the nontransformed data.

d Primary ears from all plants were visually rated for the percentage of inoculated area affected by Aspergillus ear rot. Ratings were expressed on a 0 to $100 \%$ scale in equal increments of $5 \%$, with $100 \%$ being fully rotted at the inoculation site. Values are based on the nontransformed data.

e Ear rot ratings were not recorded at these two locations. workload by identifying plants with chromosome regions of the resistant parent prior to pollinations, minimizing inoculations and enabling selection in the absence of phenotypic data.

Significant QTL associated with reduced aflatoxin concentrations in grain have been identified from inbreds Tex6 and Mp313E $(3,29,36)$. Both of these inbreds were superior sources of resistance in previous studies $(3,7,8,17,29,36)$. Inbred Tex6, developed by D. G. White, is an unreleased line derived from 'Whitemaster' Hybrid (PI401763), a southern corn cultivar from Texas (7,17). Inbred Mp313E (PI539859), was developed by G. Scott and N. Zummo by self-pollinating and selecting from the open pollinated cv. Tuxpan (32).

Reduced aflatoxin concentration in grain has been associated with QTL from two populations produced from the cross of B73 and Tex6 (29). Reduced aflatoxin concentration in grain from a $\mathrm{BCP}_{1} \mathrm{~S}_{1}$ population was associated with QTL on chromosomes 2 (bins 2.00 and 2.02), 5 (bins 5.01, 5.05, and 5.07), 8 (bin 8.05), and 10 (bins 10.05 and 10.07). Reduced aflatoxin concentration in grain from an $\mathrm{F}_{3}$ population was associated with QTL on chromosomes 2 (bins 2.02 and 2.09), 3 (bin 3.06), 4 (bin 4.08), 5 (bin 5.07), 7 (bin 7.04), 9 (bin 9.01), and 10 (bin 10.07).

Reduced aflatoxin concentration in grain from an $\mathrm{F}_{3}$ population derived from the cross B73 $\times$ Mp313E was associated with QTL on chromosome 2 (bins 2.05 to 2.07 ) in three of four environments and with QTL on chromosome 4 (bins 4.06 to 4.08) in four of four environments studied from 2000 to 2002 (3). Reduced

TABLE 8. Estimates of variance components, heritability, and expected gain from selection for aflatoxin concentration in corn grain, percent bright greenish yellow fluorescence (BGYF), and severity of Aspergillus ear rot from $217 \mathrm{BCP}_{1} \mathrm{~S}_{1}{ }^{\mathrm{a}}$ families crossed with $\mathrm{LH} 185$ and evaluated at three locations in 2002

\begin{tabular}{|c|c|c|c|c|}
\hline Location & Variance component & Aflatoxin ${ }^{b}$ & $\mathrm{BGYF}^{\mathrm{c}}$ & Ear rot ${ }^{d}$ \\
\hline \multirow[t]{5}{*}{ Urbana, IL } & Replicates & 0.02 & 0.07 & 0.07 \\
\hline & Family & 0.00 & 0.00 & 0.00 \\
\hline & Pooled error & 0.37 & 0.91 & 0.91 \\
\hline & Heritability $\left(h^{2}\right)^{\mathrm{e}}$ & 1.03 & $\mathrm{NE}^{\mathrm{f}}$ & NE \\
\hline & Expected gain & $\rho \rho$ & NIF & \\
\hline \multirow[t]{6}{*}{ Ganado, TX } & Replicates & 0.00 & $\begin{array}{r}\mathrm{NE} \\
0.02\end{array}$ & $\cdots$ \\
\hline & Family & 0.08 & 0.05 & $\cdots$ \\
\hline & Pooled error & 0.41 & 0.62 & $\ldots$ \\
\hline & Heritability $\left(h^{2}\right)^{\mathrm{e}}$ & 29.09 & $\mathrm{NE}$ & $\ldots$ \\
\hline & Expected gain & & & \\
\hline & from selection $\left(\Delta_{G}\right)^{\mathrm{g}}$ & 0.11 & $\mathrm{NE}$ & $\ldots$ \\
\hline \multirow[t]{6}{*}{ Batesville, TX } & Replicates & 0.00 & 0.00 & $\cdots$ \\
\hline & Family & 0.01 & 0.00 & $\ldots$ \\
\hline & Pooled error & 0.43 & 1.24 & $\cdots$ \\
\hline & Heritability $\left(h^{2}\right)^{\mathrm{e}}$ & 2.70 & $\mathrm{NE}$ & $\ldots$ \\
\hline & Expected gain & & & \\
\hline & from selection $\left(\Delta_{G}\right)^{\mathrm{g}}$ & 0.01 & $\mathrm{NE}$ & $\ldots$ \\
\hline
\end{tabular}

a Backcrossed to the susceptible parent (B73) and then selfed once.

b Measured by indirect-competitive enzyme-linked immunosorbent assay. Samples were analyzed in triplicate, and averaged. Values were natural logtransformed prior to statistical analysis.

c Ground samples were rated on a percent scale, with $100 \%$ being most susceptible. Ground grain samples were visually rated twice, and values were averaged. Samples were stirred between ratings. Values were square root-transformed prior to statistical analysis.

$\mathrm{d}$ Primary ears from all plants were visually rated as the percentage of inoculated area affected by Aspergillus ear rot. Ratings were expressed on a 0 to $100 \%$ scale $(0=0 \%, 100=100 \%$ rotted $)$. Values were square root-transformed prior to statistical analysis. Percent ear rot was only rated at Urbana.

e Heritabilities were calculated using the equation $h^{2}=\sigma_{\mathrm{BCP} 1 \mathrm{~S} 1}^{2} /\left[\left(\sigma^{2} e^{/ r y}\right)+\right.$ $\sigma_{\text {BCP1S1 }}^{2}$, where $\sigma^{2}{ }_{\text {BCP1S1 }}$ is the variance among $\mathrm{BCP}_{1} \mathrm{~S}_{1}$ families, $\sigma^{2}{ }_{e}$ is the pooled error variance, $r$ is the number of replicates, and $y$ is the number of years. Heritabilities were expressed as a percent.

$\mathrm{f}$ Values were not estimable due to a lack of significance among families.

g Gain from selection was calculated with the equation $\Delta_{G}=\left[k(1 / 2) \sigma^{2}{ }_{A}\right] / \sigma_{p}$, where $k$ is the constant 1.3998 (20\% selection intensity), $\sigma_{A}^{2}$ is genetic variance among $\mathrm{BCP}_{1} \mathrm{~S}_{1}$ families, and $\sigma_{p}$ is the square root of the phenotypic variance among $\mathrm{BCP}_{1} \mathrm{~S}_{1}$ families. 
aflatoxin concentration in grain also was associated with QTL on chromosomes 1 (bins 1.02 and 1.03), 3 (bin 3.05), 5 (bin 5.05), and 6 (bin 6.05); however, QTL-resistance associations were not consistent across environments.
This paper identifies QTL associated with resistance to aflatoxin accumulation in grain when alleles from Oh516 are donated to a B73 genetic background. Reduced aflatoxin concentration in grain was associated with QTL on chromosomes 2 (bins 2.01 to

TABLE 9. Chromosome bins and simple sequence repeats (SSR) ${ }^{\mathrm{a}}$ markers associated with low aflatoxin concentration in corn grain, low ear rot (\%), and low percent bright greenish yellow fluorescence $(\mathrm{BGYF})$ from two populations developed from the cross B73 $\times$ Oh516

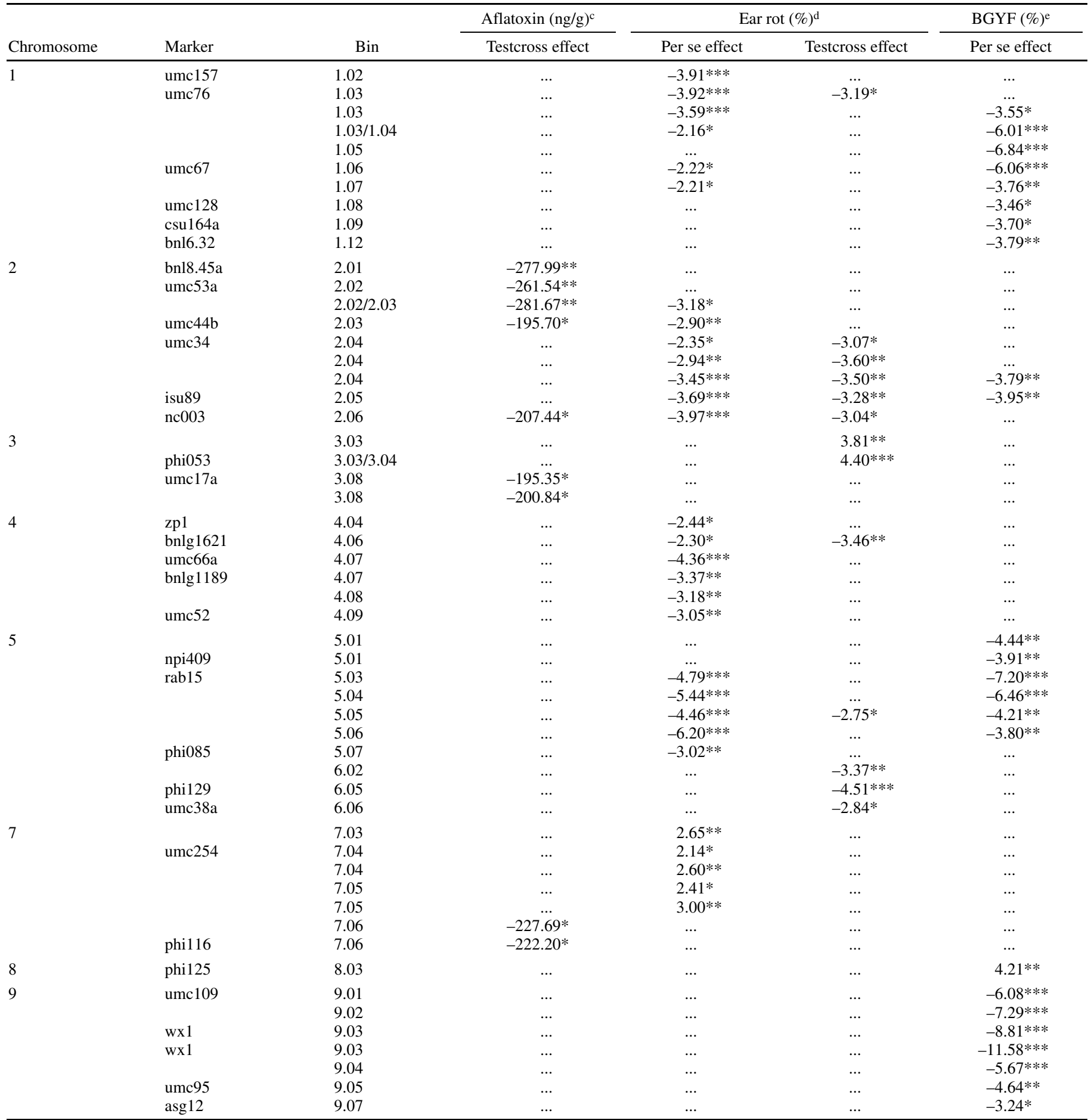

a Single nucleotide polymorphism (SNP) markers were actually used in the analyses, but the approximate SSR markers are reported due to proprietary issues with Monsanto Company (St. Louis, MO).

${ }^{b}$ Testcross population is from $217 \mathrm{BCP}_{1} \mathrm{~S}_{1}$ families crossed with $\mathrm{LH} 185$ and evaluated at three locations in 2002 . Per se population is from $265 \mathrm{BCP}_{1} \mathrm{~S}_{1}$ families evaluated in 2001 and 2002.*, **, and $* * *$ indicate significance at $\alpha=0.10,0.05$, and 0.01 , respectively. Effects are additive. Negative effects indicate allele comes from the resistant inbred Oh516, and positive effects indicate allele comes from the susceptible inbred B73.

${ }^{c}$ Aflatoxin concentration in grain (ng/g) was measured by indirect-competitive enzyme-linked immunosorbent assay. Samples were analyzed in triplicate, and values were averaged.

${ }^{\mathrm{d}}$ Severity of Aspergillus ear rot was rated as the percentage of inoculated area affected and expressed on a 0 to $100 \%$ scale $(0=0 \%, 10=100 \%$ rotted $)$.

e Ground samples were visually rated on a percent scale, with $100 \%$ being most susceptible. Ground grain samples were visually rated twice, and values were averaged. Samples were stirred between ratings. 
2.03 and 2.06), 3 (bin 3.08), and 7 (bin 7.06). Inbred Oh516 was developed from the cross $($ B14 $\times$ L97) $\times$ B14. Inbred L97, like Mp313E, was derived by self-pollinating and selecting out of the open pollinated cv. Tuxpan. Since Mp313E and Oh516 share a common ancestor, QTL on chromosome 2 (bin 2.06) identified from populations developed with Mp313E or Oh516 could describe a shared set of genes or alleles for resistance. Similarities in relative position of QTL between Oh516 and Tex6 on chromosome 2 (bin 2.02) and between Mp313E and Tex6 on chromosomes 4 (bin 4.08) and 5 (bin 5.05) lead us to believe that Tex6 also could have common ancestry. QTL-resistance associations were identified on chromosomes 2 and 3 from all three sources of resistance, indicating possible genes or alleles for lower aflatoxin concentration in grain from these chromosomes.

Reduced severity of Aspergillus ear rot was associated with alleles from Oh516 on chromosomes 1 (bins 1.02 to 1.07 and 1.12), 2 (bins 2.03 to 2.06), 4 (bins 4.04 to 4.09 ), 5 (bins 5.03 to 5.07), and 6 (bins 6.02, 6.05, and 6.06). Reduced percent BGYF was associated with alleles from Oh516 on chromosomes 1 (bins 1.03 to 1.09), 2 (bins 2.04 and 2.05), 5 (bins 5.01 to 5.06), and 9 (bins 9.01 to 9.05). QTL associated with reduced severity of Aspergillus ear rot and reduced percent BGYF from Oh516 (chromosomes 1, 2, 4, and 5) are similar in position to QTL associated with reduced aflatoxin concentration in grain from inbreds Tex6 and Mp313E. This supports our hypothesis that Oh516, Mp313E, and Tex6 may derive their resistance from southern, open pollinated varieties with common ancestry.

Additive and dominant gene effects were important for inheritance of resistance to aflatoxin accumulation in grain and resistance to percent BGYF from crosses and segregating generations developed with Oh516 and B73. Dominant gene effects accounted for almost half of the total variation in aflatoxin concentration in grain in 2001 and 2002. Potence ratios indicated partial dominance for resistance to aflatoxin concentration in grain. Aflatoxin concentration in grain of the $\mathrm{F}_{1}$ generation was significantly lower $(P<0.05)$ than the calculated midparent value in both years, which also indicates dominance for resistance. $\mathrm{BCP}_{1} \mathrm{~S}_{1}$ families being more similar to that of the resistant parent Oh516 and molecular marker data from the $\mathrm{BCP}_{1} \mathrm{~S}_{1}$ families $\times$ LH185 also supports dominant gene action as the most important factor in reducing aflatoxin concentration in grain from crosses developed with Oh516 and B73 because many alleles from Oh516 for lower aflatoxin concentration in grain were quantitatively inherited and identified in the $\mathrm{BCP}_{1} \mathrm{~S}_{1}$ generation. Previous studies with different sources of resistance found that additive and dominant gene effects were most important for reducing aflatoxin concentration in grain in the cross of B73 $\times$ LB31 (5). Additive gene action was most important for reducing aflatoxin concentration in grain in the cross of B73 $\times$ Tex6 and the cross of Mo17 × Tex6 (17). Additive and dominant gene effects were important in reducing aflatoxin concentration in grain and reducing percent BGYF in the cross of B73 $\times$ MI82 (26). Epistatic and additive gene actions were most important for reducing aflatoxin concentration in grain in the cross of B73 × CI2 in 1998 and 1999, respectively (35).

Testcrosses developed with $\mathrm{BCP}_{1} \mathrm{~S}_{1}$ families and LH185 provided a valuable assessment of inbred Oh516 for improving future commercial hybrids. Testcross hybrids approximate the performance of commercial hybrids because they are vigorous and able to withstand stressful environments. The trials in Texas allowed evaluation of resistance in environments that are often more conducive to Aspergillus ear rot and aflatoxin concentrations in grain than environments in the Midwest. In 2002, drought conditions in southern Texas, despite irrigation throughout the growing season, resulted in growing conditions that predisposed corn plants to extreme stress, causing great aflatoxin accumulation in grain in several of the testcross families.

Resistance to aflatoxin accumulation in grain is quantitatively inherited, highly influenced by the environment, and poorly heritable. Heritability estimates of 1.0 and $2.7 \%$ for resistance to aflatoxin accumulation in grain from the testcross trials at Urbana and Batesville were smaller than estimates from other studies and other sources of resistance at the University of Illinois $(5,17$, 26,35). However, the heritability estimate of $29.1 \%$ for resistance to aflatoxin accumulation in grain from Ganado was much greater than the estimate reported by Walker and White (35) for the $\mathrm{BCP}_{1} \mathrm{~S}_{1}$ generation of the $\mathrm{B} 73 \times \mathrm{CI} 2$ cross. The heritability estimate of $21 \%$ for reduced percent BGYF from our generation means study is lower than the heritability estimate reported by Maupin et al. (26) for the $\mathrm{BCP}_{1} \mathrm{~S}_{1}$ generation of the $\mathrm{B} 73 \times \mathrm{MI} 82$ cross. The heritability estimate of $11 \%$ for reduced severity of Aspergillus ear rot from our generation means study also is lower than the heritability estimates of 63 and $58 \%$ reported in studies of the B73 $\times$ MI82 and Mo17 × Tex6 cross $(17,26)$. Small heritability estimates for all traits evaluated in our studies of Oh516 are likely due to small family variance components; therefore, it is difficult to select for those traits of interest and limits corn breeders to using marker assisted selection as the only valid mean of selecting for resistance to these traits.

Selection based on low percent BGYF could be used as an initial, indirect method of selection for low aflatoxin concentration in grain. This method of selection should reduce time and labor and decrease the number of samples quantitatively analyzed for aflatoxin concentration in grain. Maupin et al. (26) reported highly significant correlations of $r=0.75$ and 0.79 for aflatoxin concentration in grain and percent BGYF in a study of the cross B73 $\times$ MI82. In our generation means study of B73 $\times$ Oh516, there also was a significant relationship between aflatoxin concentration in grain and percent BGYF. However, correlation values of $r=0.67$ and 0.59 are not high enough for breeders to confidently select families with low aflatoxin concentration in grain based on low percent BGYF. The correlation between aflatoxin concentration in grain and percent BGYF from the testcross trials also was significant in two of three locations. However, correlations were not as high as those determined from the generation means study. Therefore, use of BGYF as an indirect selection method for low aflatoxin concentrations in grain from genotypes in a segregating generation may vary with the source of resistance.

Inbred Oh516 has agronomic traits that are favorable compared to the extremely poor agronomic traits of other sources of resistance like Tex6 and Mp313E. One of the progenitor lines of Oh516 is the historically important inbred B14. Inbred B14, a line derived from Stiff Stalk Synthetic, was used in the development of several modern commercial hybrids because it imparts superior yield, excellent root and stalk strength, and fast dry down to maturity (34). Therefore, inbred Oh516 not only provides a great source of resistance that can be readily incorporated, but also provides agronomic traits that mimic those of commercial inbreds used today.

\section{ACKNOWLEDGMENTS}

Any opinions, findings, and conclusions or recommendations expressed in this publication are those of the authors and do not necessarily reflect the views of the University of Illinois or Monsanto Company. We are especially grateful to Monsanto Company (St. Louis, MO) for funding the molecular marker analysis and finding and providing the field space in Texas. We thank M. R. Kerns and S. R. Eathington from Monsanto Company for the molecular marker analysis; M. J. Clements from USDAARS Mississippi State University for reviewing and assisting with this manuscript; T. R. Rocheford for producing the 265 backcross to the susceptible self families; R. Polasek for assisting with the preparation of the plots and inoculations in Texas; J. W. Dudley for assistance with genetic equations; D. C. Clark for assistance with marker analysis; G. Bollero for assistance with statistical analysis; and M. J. Clements, C. E. Kleinschmidt, L. M. Maupin, S. R. Phillips, and S. K. Sipp for assistance with laboratory and field work. 


\section{LITERATURE CITED}

1. Anderson, H. W., Nehring, E. W., and Wischer, W. R. 1975. Aflatoxin contamination of corn in the field. J. Agric. Food Chem. 23:775-782.

2. Bodine, A. B., and Mertens, D. R. 1983. Toxicology, metabolism, and physiological effects of aflatoxin in the bovine. Pages 46-50 in: Aflatoxin and Aspergillus flavus in Corn. U. L. Diener, R. L. Asquith, and J. W. Dickens, eds. Auburn Univ. So. Coop. Series Bull. 279.

3. Brooks, T. D., Williams, W. P., Windham, G. L., and Abbas, H. K. 2003. Molecular characterization of resistance to aflatoxin accumulation in Mp313E. Page 62 in: Proc. Aflatoxin/Fumonisin Elimination and Fungal Genomics Workshop. U.S. Department of Agriculture-Agriculture Research Service.

4. Brown, R. L., Chen, Z.-Y., Cleveland, T. E., and Russin, J. S. 1999. Advances in the development of host resistance in corn to aflatoxin contamination by Aspergillus flavus. Phytopathology 89:113-117.

5. Campbell, K. W., Hamblin, A. M., and White, D. G. 1997. Inheritance of resistance to aflatoxin production in the cross between corn inbreds B73 and LB31. Phytopathology 87:1144-1147.

6. Campbell, K. W., and White, D. G. 1994. An inoculation device to evaluate maize for resistance to ear rot and aflatoxin production by Aspergillus flavus. Plant Dis. 78:778-781.

7. Campbell, K. W., and White, D. G. 1995. Evaluation of corn genotypes for resistance to Aspergillus ear rot, kernel infection, and aflatoxin production. Plant Dis. 79:1039-1045.

8. Campbell, K. W., and White, D. G. 1995. Inheritance of resistance to Aspergillus ear rot and aflatoxin in corn genotypes. Phytopathology 85:886-896.

9. Darrah, L. L., Lillehoj, E. B., Zuber, M. S., Scott, G. E., Thompson, D., West, D. R., Widstrom, N. W., and Fortnum, B. A. 1987. Inheritance of aflatoxin $\mathrm{B}_{1}$ levels in maize kernels under modified natural inoculation with Aspergillus flavus. Crop Sci. 27:869-872.

10. Davis, N. D., and Diener, U. L. 1983. Some characteristics of toxigenic and nontoxigenic isolates of Aspergillus flavus and Aspergillus parasiticus. Pages 1-5 in: Aflatoxin and Aspergillus flavus in Corn. U. L. Diener, R. L. Asquith, and J. W. Dickens, eds. Auburn Univ. So. Coop. Series Bull. 279.

11. Dudley, J. W. 1992. Theory for identification of marker locus-QTL associations in population by line crosses. Theor. Appl. Genet. 85:101-104.

12. Dudley, J. W. 1993. Molecular markers in plant improvement: Manipulation of genes affecting quantitative traits. Crop Sci. 33:660-668.

13. Edds, G. T., and Bortell, R. A. 1983. Biological effects of aflatoxinpoultry. Pages 56-61 in: Aflatoxin and Aspergillus flavus in Corn. U. L. Diener, R. L. Asquith, and J. W. Dickens, eds. Auburn Univ. So. Coop. Series Bull. 279.

14. Gardner, C. A. C., Darrah, L. L., Zuber, M. S., and Wallin, J. R. 1987. Genetic control of aflatoxin production in maize. Plant Dis. 71:426-429.

15. Gorman, D. P., Kang, M. S., Cleveland, T., and Hutchinson, R. L. 1992. Combining ability for resistance to field aflatoxin accumulation in maize grain. Plant Breed. 109:296-303.

16. Hallauer, A. R., and Miranda, J. B. 1988. Quantitative Genetics in Maize Breeding. 2nd ed. Iowa State University Press, Ames, Iowa.

17. Hamblin, A. M., and White, D. G. 2000. Inheritance of resistance to Aspergillus ear rot and aflatoxin production of corn from Tex6. Phytopathology 90:292-296.

18. Henry, S. H., Bosch, F. X., Troxell, T. C., and Bolger, P. M. 1999. Reducing liver cancer-global control of aflatoxin. Science 286:2453-2454.

19. Hoerr, F. J., and D'Andrea, G. H. 1983. Biological effects of aflatoxin in swine. Pages 51-55 in: Aflatoxin and Aspergillus flavus in Corn. U. L. Diener, R. L. Asquith, and J. W. Dickens, eds. Auburn Univ. So. Coop. Series Bull. 279.
20. Lawrence, C. J., Dong, Q., Polacco, M. L. Seigfried, T. E., and Brendel, V. 2004. MaizeGDB, the community database for maize genetics and genomics. Nucleic Acids Res. 32:D393-D397.

21. Lillehoj, E. B., Kwolek, W. F., Horner, E. S., Widstrom, N. W., Josephson, L. M., Franz, A. O., and Catalano, E. A. 1980. Aflatoxin contamination of preharvest corn: Role of Aspergillus flavus inoculum and insect damage. Cereal Chem. 57:255-257.

22. Lillehoj, E. B., Kwolek, W. F., Manwiller, A., DuRant, J. A., LaPrade, J. C., Horner, E. S., Reid, J., and Zuber, M. S. 1976. Aflatoxin production in several corn hybrids grown in South Carolina and Florida. Crop Sci. 16:483-485.

23. Lillehoj, E. B., Kwolek, W. F., Zuber, M. S., Bockholt, A. J., Calvert, O. H., Findley, W. R., Guthrie, W. D., Horner, E. S., Josephson, L. M., King, S., Manwiller, A., Sauer, D. B., Thompson, D., Turner, M., and Widstrom, N. W. 1980. Aflatoxin in corn before harvest: Interaction of hybrids and locations. Crop Sci. 20:731-734.

24. Marsh, P. B., Simpson, M. E., Ferretti, R. J., Merola, G. V., Donoso, J., Craig, G. O., Trucksess, M. W., and Work, P. S. 1969. Mechanism of formation of a fluorescence in cotton fiver associated with aflatoxin in the seeds at harvest. Agric. Food Chem. 17:468-472.

25. Mather, K., and Jinks, J. L. 1982. Biometrical Genetics. 3rd ed. Chapman and Hall, London.

26. Maupin, L. M., Clements, M. J., and White, D. G. 2003. Evaluation of the MI82 corn line as a source of resistance to aflatoxin in grain and use of BGYF as a selection tool. Plant Dis. 87:1059-1066.

27. Maupin, L. M., White, D. G., and Perkins, J. M. 2002. Evaluation of inoculation methods for Aspergillus ear rot and aflatoxin contamination of corn. (Abstr.) Phytopathology 92(suppl.):S53.

28. Naidoo, G., Forbes, A. M., Paul, C., White, D. G., and Rocheford, T. R. 2002. Resistance to Aspergillus ear rot and aflatoxin accumulation in maize $\mathrm{F}_{1}$ hybrids. Crop Sci. 42:360-364.

29. Paul, C., Naidoo, G., Forbes, A., Mikkilineni, V., White, D., and Rocheford, T. 2003. Quantitative trait loci for low aflatoxin production in two related maize populations. Theor. Appl. Genet. 107:263-270.

30. Payne, G. A. 1992. Aflatoxin in maize. Crit. Rev. Plant Sci. 10:423-440.

31. Scott, G. E. 1996. Association of bright greenish yellow fluorescence and aflatoxin in grain of maize inbreds. Maydica 41:43-48.

32. Scott, G. E., and Zummo, N. 1990. Registration of Mp313E parental line of maize. Crop Sci. 32:1296.

33. Shotwell, O. L., Gooulden, M. L., and Hesseltine, C. W. 1972. Aflatoxin contamination: Association with foreign material and characteristic fluorescence in damaged corn kernels. Cereal Chem. 49:458-465.

34. Troyer, A. F. 1999. Background of U.S. hybrid corn. Crop Sci. 39:601626.

35. Walker, R. D., and White, D. G. 2001. Inheritance of resistance to Aspergillus ear rot and aflatoxin production of corn from CI2. Plant Dis. 85:322-327.

36. White, D. G., and Rocheford, T. 2002. Breeding and molecular marker assisted selection for resistance to Aspergillus ear rot and aflatoxin production. Mycopathologia 155:79.

37. Wicklow, D. T. 1999. Influence of Aspergillus flavus strains on aflatoxin and bright greenish yellow fluorescence of corn kernels. Plant Dis. 83:1146-1148.

38. Zuber, M. S., Calvert, O. H., Kwolek, W. F., Lillehoj, E. B., and Kang, M. S. 1978. Aflatoxin $\mathrm{B}_{1}$ production in an eight-line diallel of Zea mays infected with Aspergillus flavus. Phytopathology 68:1346-1349.

39. Zuber, M. S., Darrah, L. L., Lillehoj, E. B., Josephson, L. M., Manwiller, A., Scott, G. E., Gudauskas, R. T., Horner, E. S., Widstrom, N. W., Thompson, D. L., Bockholt, A. J., and Brewbaker, J. L. 1983. Comparison of open-pollinated maize varieties and hybrids for preharvest aflatoxin contamination in the southern United States. Plant Dis. 67:185-187. 